\title{
New alien barnacles in the Azores and some remarks on the invasive potential of Balanidae
}

\author{
Paulo Torres $\cdot$ Ana Cristina Costa $\cdot$ \\ Maria Ana Dionísio
}

Received: 29 March 2011/Revised: 22 November 2011/Accepted: 12 December 2011/Published online: 28 December 2011 (C) Springer-Verlag and AWI 2011

\begin{abstract}
Global homogenization of biota is underway through worldwide introduction and establishment of nonindigenous (exotic) species. Organisms fouling ship hulls are continually in transit and can affect communities through biodiversity loss and serious damage to economy and public health. In the Azores, for the first time, underwater alien species prospection was conducted in marinas and recreational harbours, at São Miguel Island. Populations of three locally previously unknown barnacle species were found: Amphibalanus amphitrite, Amphibalanus eburneus and Perforatus perforatus. These species account for the more than $50 \%$ of alien barnacles worldwide that belong to Balanidae family. Hence, some considerations about morphology and life cycle of this family are advanced, discussed and related to their invasive potential.
\end{abstract}

Keywords Barnacles - Marine alien species - Invasive potential $\cdot$ Balanidae $\cdot$ Azores

\section{Introduction}

Over recent centuries, many marine species have been transported around the globe by human activities. Nowadays, the introduction of non-indigenous species is an issue of global concern due to its potential impacts on biodiversity economy and public health. Hull fouling, ballast

Communicated by Heinz-Dieter Franke.

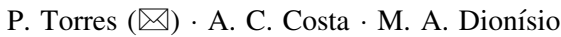
CIBIO-Pólo Açores e CCPA, Departamento de Biologia, Universidade dos Açores, Rua Mãe de Deus, 58, 9500-801 Ponta Delgada, Açores, Portugal

e-mail: biol.paulo@gmail.com water, fisheries, aquaculture and recreational boating contribute to the spreading of marine species to areas far outside of their natural dispersal potential (Bax et al. 2003).

Ocean-going vessels act as "mobile stepping stones" for fouling species from harbours and estuaries, providing a substratum from which attached adults can release larvae in suitable situations (Apte et al. 2000). Fouled ships have plied the oceans since the beginning of oceanic navigation, but changing trading routes, increased traffic volume and speed and relatively long port residence times have effectively facilitated the crossing of substantial distances and biogeographical barriers by marine organisms (Carlton 1985).

Biofouling can cause roughness of submerged surfaces of marine structures (Chakrabarti 1991), increase hydrodynamic loadings (Wolfram and Theophanatos 1985), accelerate corrosion processes (Patil et al. 1988) and impede underwater inspection and maintenance (Houghton 1978). The inadequacy of data will likely cost money in overdesign, failure of structures or damage to the environment. Thus, the extent and type of biological fouling and the development of fouling communities should be ascertained before engaging in economic activities in offshore waters.

The dispersal of marine organisms by shipping has long been used in interpreting the biogeography of marine invertebrates (Foster and Willan 1979; Carlton and Geller 1993; Zardus and Hadfield 2005). One of the first welldocumented introductions of a barnacle by shipping was that of Austrominius modestus (= Elminius modestus) (Darwin, 1854) from New Zealand to England, most likely via convoys during World War II (Southward et al. 1998).

Barnacles, a highly successful group in terms of global dispersion (Newman and Ross 1976), are usually found in aggregations of conspecifics and other fouling organisms 
(Arnsberg 2001). At present, many barnacle species are extending their geographical range, spreading to regions where they did not occur before (Zullo 1992).

Cirripedia can be transported as fouling on the hull of ships or as larvae in ballast water. In fact, ballast water often contains larvae of littoral or harbour cirriped species (e.g. Carlton 1985; Carlton and Geller 1993; Lavoie et al. 1999). Being able to survive for a long time in ballast tanks, larvae when released from these tanks may successfully settle in a new environment. Larvae may also originate from gravid individuals present on ship hulls. Larvae settle on hulls of ships staying in harbours and then can grow very quickly while carried away to others areas. Many barnacles have taken advantage of this opportunity to reach new regions where they often successfully colonized harbour installations, pontoons, floating objects such as buoys, and other hard substrata (Bishop 1951; Southward 1975).

The volcanic islands of the Azores were shaped relatively recently and are one of the youngest groups of oceanic island in the Central Atlantic. Given the islands' location and age, their colonization by marine organisms is believed to occur mainly through oceanic currents. Little is known on anthropogenic introductions of marine species in the Azores as only a single study was published on Azorean marine aliens (Cardigos et al. 2006). Nevertheless, the islands are exposed to a high risk of species introductions, considering the increase in transatlantic leisure boat traffic and commercial maritime traffic stopping at the islands over the last decade, not to mention potential naturalizations since the fifteenth century when the discovery of the archipelago resulted in an obligatory stop over for most ships crossing the north Atlantic or on their way to Africa and India.

Given the unique position of the islands far from continental Europe in the heart of the Atlantic, the invasive susceptibility of the archipelago as well as barnacles' life cycle and invasive potential, this study intended to identify alien barnacle species established in the marina harbours of Ponta Delgada, on the Island of São Miguel, Azores. Furthermore, the invasive potential of the Balanidae is discussed, with special reference to the Azores.

\section{Materials and methods}

\section{Study area}

The archipelago of the Azores $\left(36-39^{\prime} \mathrm{N}, 25-31^{\circ} \mathrm{W}\right)$ consists of nine volcanic islands forming three groups (western, central and eastern) along a tectonic zone running about $600 \mathrm{~km}$ (Fig. 1a). The islands emerged at a triple junction along the mid-Atlantic Ridge, separated from the continent by at least $1,300 \mathrm{~km}$ (Morton et al. 1998). The coastline is largely rocky, with boulder shores and frequently with cliffs up to $500 \mathrm{~m}$.

The oceanographic conditions in the Azores are strongly influenced by the Gulf Stream, which, in the central North Atlantic, has a southern multibranched current system with many unstable meanders and eddies at the Azores front (Gould 1985; Pollard and $\mathrm{Pu}$ 1985). Average winter and summer sea surface temperatures are $15-16$ and $22-24^{\circ} \mathrm{C}$, respectively (Santos et al. 1995). Oceanic waters present low productivity with primary production below $150 \mathrm{mg}$ $\mathrm{C} \mathrm{m}^{-2}$ year $^{-1}$ (Raymont 1980). All Azorean islands were uninhabited by humans until the late fifteenth century, when they were colonized by Portuguese.

In spite of a long history of exploitation of littoral marine resources, the pressure on the littoral zone has been increasing in recent years with dumping of solid wastes, fisheries, recreation, infrastructure activities (harbours, roads) and tourist developments (Depledge et al. 1992; Santos et al. 1995). Ponta Delgada's marina harbour has recently quadruplicated its number of berths to about 670 . The new marina is part of the Sea Gateways project, which also includes a cruise ships' quay. Both marinas, the new extension and the old one, are surrounded by rocks, have a maximum depth of about $7 \mathrm{~m}$ and are located within the larger commercial harbour area (Fig. 1c).

\section{Field and laboratory procedures}

Underwater surveys were conducted in the subtidal areas (maximum of $10 \mathrm{~m}$ depth) at the pontoons and peers of the marinas and the harbour of Ponta Delgada, São Miguel Island, Azores, to sample and identify alien barnacle species. All species were recorded and collected for later identification.

A species was considered alien to the Azores when the following criteria were met: (1) it is new to the Azores; (2) its occurrence in the Azores constitutes a geographic discontinuity to the species' known range; (3) the extension of its range can be linked, directly or indirectly, to human activities; (4) its new occurrence is at first very localized; and (5) a persisting population has been established.

Identification of barnacles (mainly based on size, shape and number of calcareous, parietal plates) was performed according to Dionísio et al. (2011). Also, the shape and relative size of the movable, opercular plates (tergum and scutum) were considered. Colour and ornamentation of the plates are useful for some species. For identification in the laboratory, 10 complete, fresh (not preserved) specimens of each species, representing the full adult range size, were selected and photographed. The barnacles were dissected, and the pattern and colour of the wall plates and the tergoscutal flaps were recorded (see Southward and 
Fig. 1 Study area. A Azores; $B$ São Miguel Island; $C$ Ponta Delgada harbour; $D$ Marina harbours

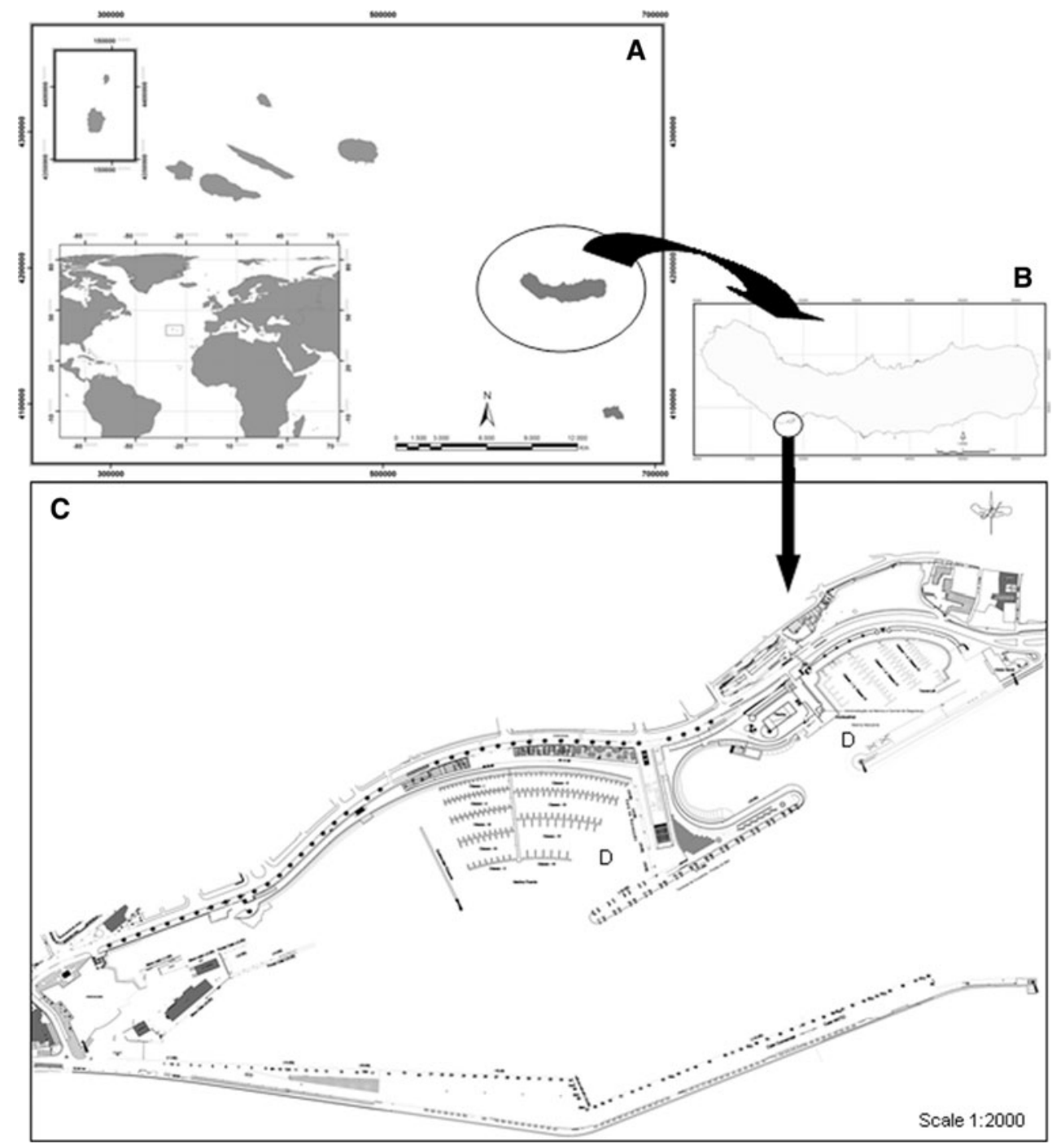

Crisp 1963). The opercular plates and soft parts of the body were removed from the wall plates. Operculum maximum diameter, basal maximum diameter, carinal height, rostral height, width and length of right and left tergum and scutum were measured to the nearest $0.05 \mathrm{~mm}$ using digital callipers. The scuta and terga were then immersed in concentrated sodium hypochlorite solution for 2 days and rinsed thoroughly in water, and the inner sides were examined and photographed under a compound microscope with an attached Cannon Power Shot G6 camera.

\section{Results}

Three exotic cirriped species new to the Azores were recorded at the marina harbour of Ponta Delgada, occurring at the sampled pontoons, attached to the metal pillars down to $5 \mathrm{~m}$ depth or to the pontoons themselves (PVC substrate) at water level: two species of the genus Amphibalanus (generic name changed according to Pitombo 2004), Amphibalanus amphitrite (Darwin, 1854) and Amphibalanus eburneus (Gould, 1841), and further Perforatus perforatus (Bruguière, 1789). The latter species dominated the barnacle fauna along with Balanus trigonus Darwin, 1854, an exotic species which has already established itself in the Azores.

All three species were found in clusters in distinct sites and were represented by individuals of different size including mature specimens. This indicates their potential to maintain self-sustaining populations in the area.

Amphibalanus amphitrite (Darwin, 1854)

Amphibalanus amphitrite (Fig. 2) is a cosmopolitan tropical and subtropical species (Newman and Ross 1976) that 


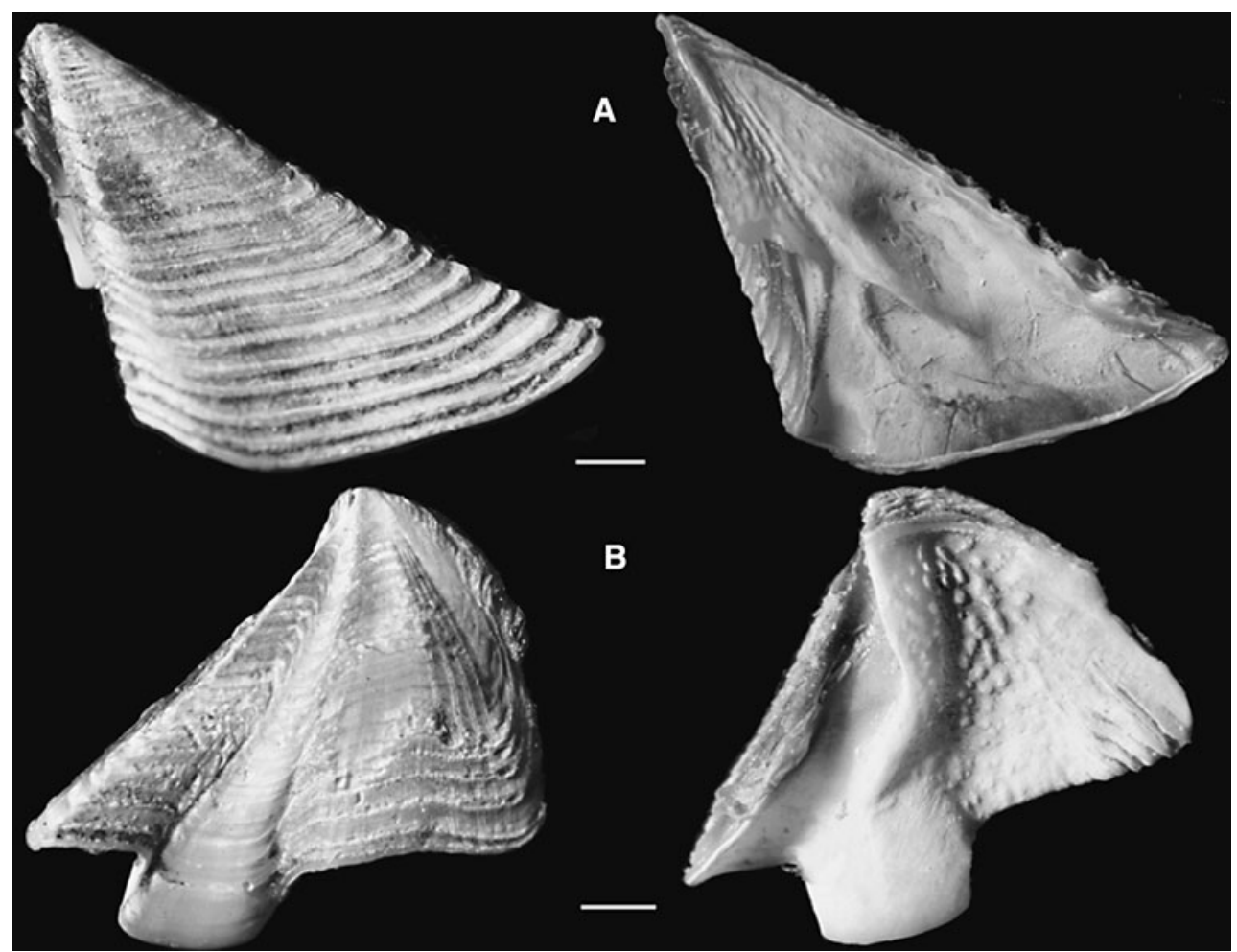

Fig. 2 Amphibalanus amphitrite collected at Ponta Delgada, Azores. A scuta (left external, right internal), B terga (left external, right internal). Scale bar $1 \mathrm{~mm}$

normally occurs intertidally, often in brackish waters (Henry and McLaughlin 1975). Looking at Darwin's type material, Harding (1962) established that its origin was Natal, South Africa. But several current authors (see Carlton et al. 2011) have considered the species to originate from the Indo-Pacific Ocean. Furthermore, several other authors (e.g. Farrapeira 2009) classified it as cryptogenic. It is a typical fouling and harbour species, able to withstand low salinity levels (Southward 1975; Utinomi 1960) and often abundant in habitats exposed to physical stress and pollution (Lipkin and Safriel 1971; Shkedy et al. 1995). In tropical and subtropical areas, A. amphitrite occurs abundantly in the intertidal zone of sheltered coasts, usually below the mean seawater level. In more northern temperate areas such as the Japanese and Californian coasts, the species is generally restricted to enclosed bays or harbours (Utinomi 1960). Along the western European coasts, this species was considered to live mainly in harbours and, in the eastern Channel and the southern North Sea, at sites where temperature was artificially raised (Bishop 1950; Southward and Crisp 1963; Hayward and Ryland 1999).

In the Azores, this species was reported for Faial (Gruvel 1920), but its presence was not confirmed ever since. In fact, Young (1998) doubted the unconfirmed record.

\section{Amphibalanus eburneus (Gould, 1841)}

This large barnacle is native to the east coast of the USA, from Nova Scotia to Florida, including the Caribbean and Gulf of Mexico (Kaplan 1988). Nowadays, the ivory barnacle is found worldwide probably due to introductions via ballast water and hull fouling of ships (e.g. Hawaii, see Matsui et al. 1964). It is a typical fouling species introduced in Europe about 100 years ago and is well established in waters of reduced salinity in the Mediterranean and in the southern Bay of Biscay (Southward 1962). A. eburneus (Fig. 3) can be found on a variety of hard surfaces from the low tide line to a depth of about $37 \mathrm{~m}$ (Voss 1980), including rocks; oysters; mussels and other mollusc shells; pilings; buoys; seawalls; and even prop roots of mangroves (Kaplan 1988).

For the Azores, Southward (1998) confirmed the species' presence, in small numbers, at the waterline of stagnant pools in the nearly dried-out estuary at the north end of Horta Bay at Faial Island. This species was present in fewer numbers on pontoons below the water line.

Perforatus perforatus (Bruguière, 1789)

Perforatus perforatus is an eastern Atlantic warmwater species, occurring commonly in the Mediterranean 


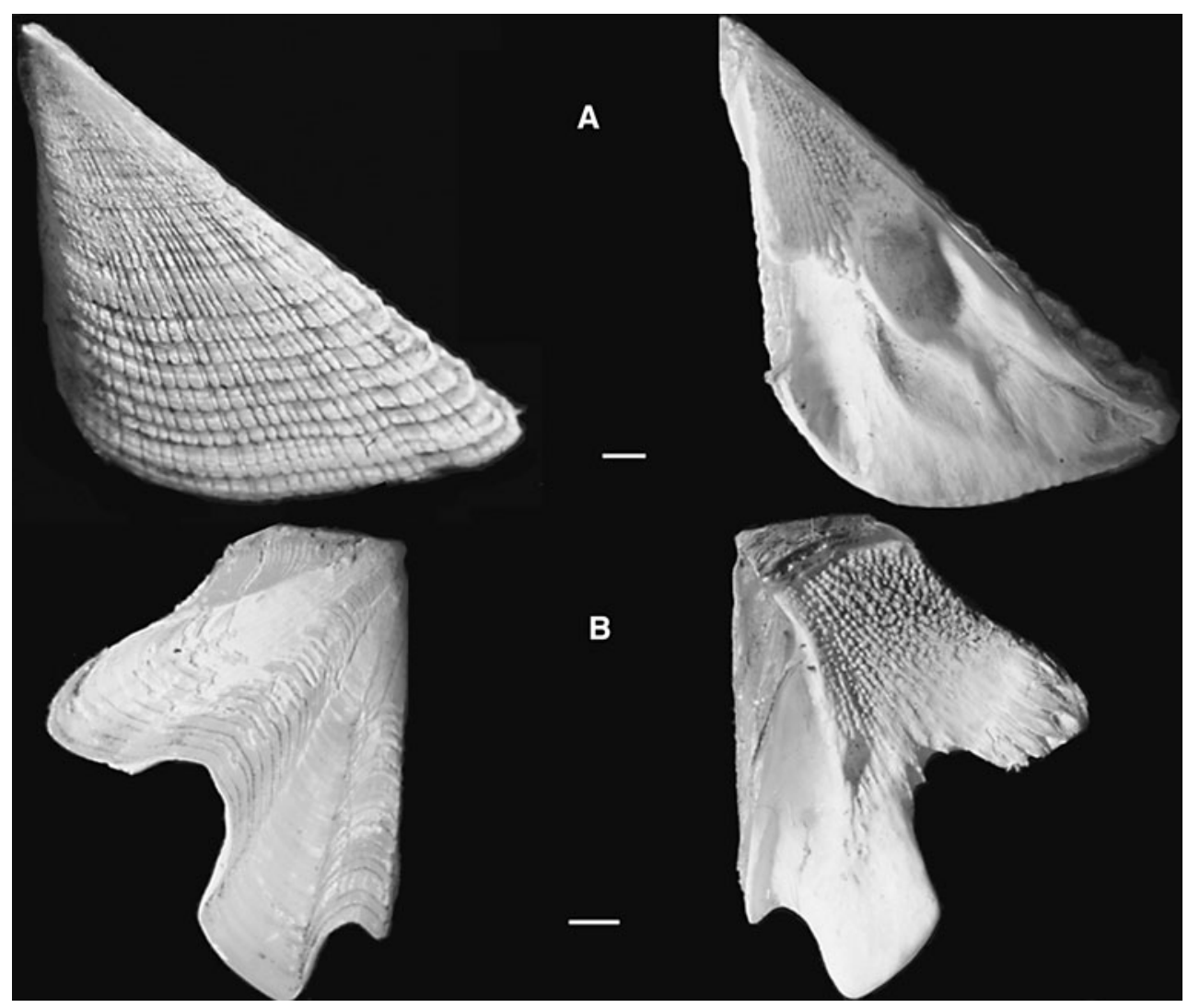

Fig. 3 Amphibalanus eburneus collected at Ponta Delgada, Azores. A scuta (left external, right internal), B terga (left external, right internal). Scale bar $1 \mathrm{~mm}$

(Koukoura and Matsa 1998). Its range extends southward to the north-western coast of Africa. Along the English Channel, it occurs up to the Isle of Wight (Stubbings 1967). P. perforatus (Fig. 4) is a shallow-water species, common on wave-exposed shores. It is usually found near the low water mark and does not extend far into the subtidal zone. Near the northern limit of its distribution, it tends to be confined to the sublittoral zone and to embayed locations (Bassindale 1964). In the southern North Sea, the species is regularly found on drifting objects washed ashore (Pelseneer 1881a, b). In 1978, it was recorded from buoys off the Dutch coast (Buizer 1978, 1980). It is the largest common shore barnacle of northwest Europe, but on drifting objects, usually only small individuals occur.

For the Azores, this is the first record of $P$. perforatus.

\section{Discussion}

Balanidae: an invasive family?

It is not fully clear what makes a successful invader. Factors that have been considered in the literature include the ability to survive the process of introduction (conditions and duration), the ability to form resting stages, special life-history traits (e.g. pelagic larval dispersal, direct development, high reproduction rate), the capacity to overcome abiotic stress and to adapt to a new trophic niche, and special features of the recipient environment that prevent or facilitate survival and establishment of new species. However, a clear picture has not yet emerged (Streftaris et al. 2005).

Cirripedia is one of the most common groups of organisms in the fouling communities on ship hulls (Gollasch et al. 2002; Godwin 2003). This may have contributed considerably to the cosmopolitan or circumtropical distribution of several species, especially of those adapted to physiologically rigorous environments such as in estuaries and harbours (Van Syoc 2009).

The Cirripedia have evolved several morphological, physiological and larval features that allow for spreading with subsequent colonization of and adaptation to new areas. The primitive balanomorphs were characterized by loss of the peduncle and by a skeleton composed of eight parietal and smaller accessory plates (Palmer 1982). In the course of their radiation, most balanomorphs reduced the number of plates while increasing their mechanical 


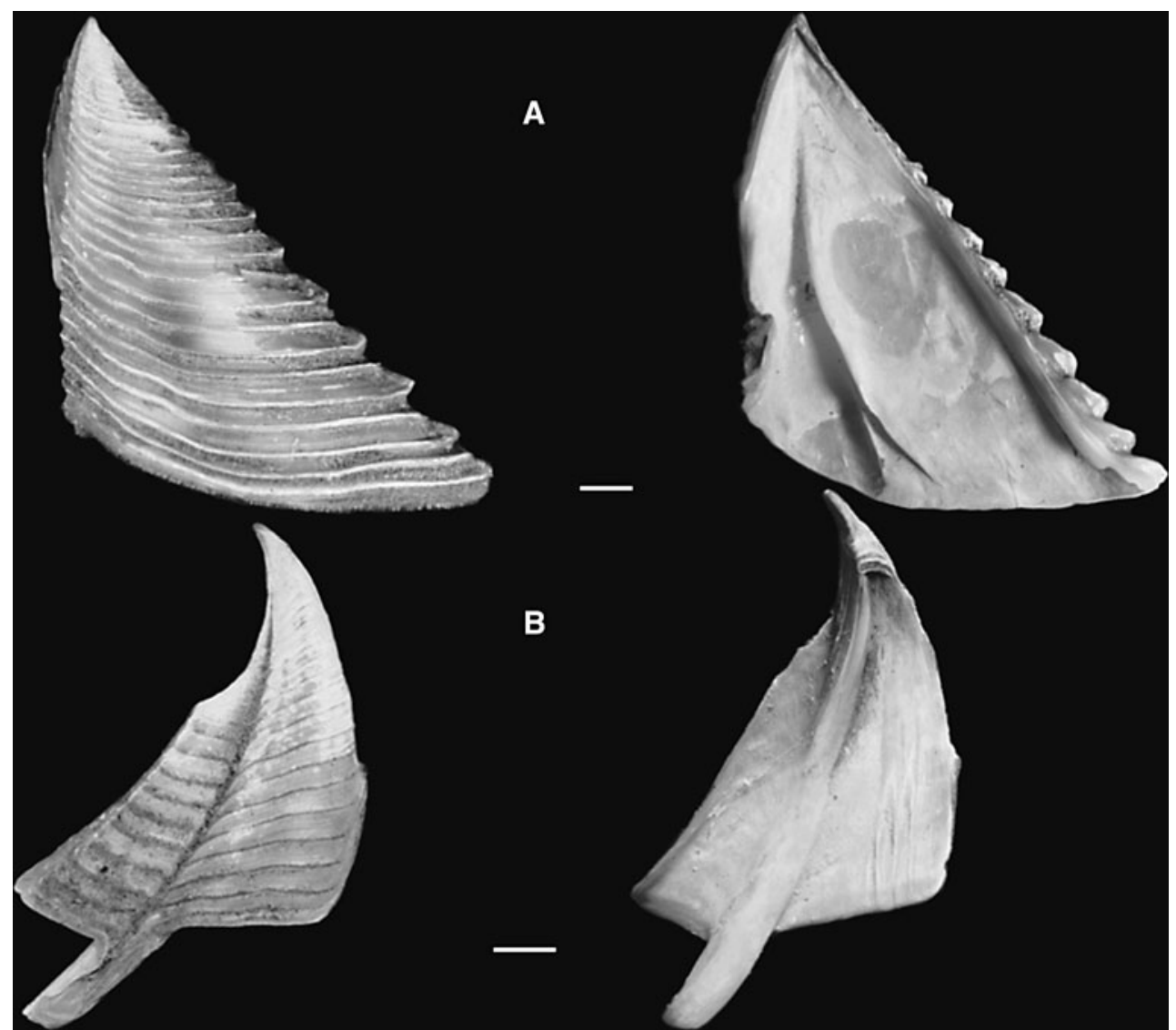

Fig. 4 Perforatus perforatus collected at Ponta Delgada, Azores. A scuta (left external, right internal), B terga (left external, right internal). Scale bar $1 \mathrm{~mm}$

strength (Newman et al. 1969). This evolutionary process may be regarded as a successful adaptation to intertidal life, in particular with respect to wave action and predator resistance (Palmer 1982). According to Van Syoc (2009), the shell combined with planktonic larval dispersal enables some Cirripedia species to invade and persist in diverse and physiologically challenging environments.

Balanomorph barnacles settle and grow on a wide range of substrata in the sea and thus have become a serious problem as fouling organisms on ships and industrial installations (Crisp 1976). Advantages of such site selection may be found in avoidance of smothering on the sea floor by detritus or competitive colonial animals and seaweeds, avoidance of predators, conveyance to alternative water masses, improved feeding and increased aggregation to enhance cross-fertilization. Gregarious behaviour may also be an important adaptive feature, since barnacles save energy for growth and reproduction, which would otherwise be used for locomotion and defence (Wu et al. 1977). Barnacles follow the r-strategy, which is characterized by high fecundity and larvae with short development time. This strategy occurs mainly with species specialized in rapidly colonizing new habitats or with species with strongly fluctuating population sizes (Foster 1987), two features generally reported for exotic species.

The duration of the larval development, a key feature for dispersal, depends on temperature and varies in laboratory cultures (Table 1). Larvae of A. amphitrite and A. eburneus can reach an age of about 17 and 13 days, respectively. In fact, cyprid larvae of $A$. eburneus can successfully settle one to three days following the final naupliar moult

Table 1 Duration of larval development

\begin{tabular}{llll}
\hline Species & $\begin{array}{l}\text { Duration } \\
\text { of larval } \\
\text { development } \\
\text { (days) }\end{array}$ & $\begin{array}{l}\text { Temperature } \\
\left({ }^{\circ} \mathrm{C}\right)\end{array}$ & Reference \\
\hline $\begin{array}{c}\text { Amphibalanus } \\
\text { amphitrite }\end{array}$ & $7-17$ & $20-26$ & $\begin{array}{c}\text { Costlow and } \\
\text { Bookhout (1958) }\end{array}$ \\
$\begin{array}{c}\text { Amphibalanus } \\
\text { eburneus }\end{array}$ & $7-13$ & 26 & $\begin{array}{c}\text { Costlow and } \\
\text { Bookhout (1958) }\end{array}$ \\
$\begin{array}{c}\text { Perforatus } \\
\text { perforatus }\end{array}$ & $7-15$ & $16-25$ & $\begin{array}{c}\text { Yule (personal } \\
\text { communication) }\end{array}$ \\
\hline
\end{tabular}


(Costlow and Bookhout 1957). In the laboratory, P. perforatus requires $16-17^{\circ} \mathrm{C}$ to produce larvae, but multiple broods can be produced when conditions remain favourable (Patel and Crisp 1960). The larvae are small, and at $25^{\circ} \mathrm{C}$, they are ready to settle within 1 week after hatching. Taking into account the duration of the brooding period and the average temperatures reported for the Azores, the three reported species may produce 2-3 generations of larvae over the summer-autumn season.

Given the predominance of alien species among the Balanidae of the Azores, a literature survey (Table 2) was conducted to evaluate the invasion potential of this barnacle family in different areas around the world (Fig. 5). The high percentages of Balanidae species considered exotic for any location studied give proof of an extraordinarily high invasive potential of this taxon. Out of a total of 185 barnacle species worldwide, 128 (69\%) Balanidae species have been reported as alien for some locations. Thus, any effort should be made to identify and monitor these marine aliens before they may propagate, establish themselves and impact native populations.

\section{Balanidae in the Azores}

The Azorean shallow-water barnacles show a rather low diversity. This may reflect the insular position, the young age and small size of the islands as well as the absence of

Table 2 Studies on exotic barnacles performed at different locations

\begin{tabular}{ll}
\hline Location & Reference \\
\hline $\begin{array}{l}\text { Aegean, Marmara, Black, } \\
\text { Azov and Caspian Seas }\end{array}$ & Panov (2004) \\
Australia & Jones (1992) \\
Azores & Southward (1998) \\
Baltic Sea & Leppäkoski and Gollasch (2006) \\
Belgium & Kerckhof and Cattrijsse (2001) \\
& Kerckhof et al. (2007) \\
Brazil & Farrapeira (2008) \\
& Farrapeira (2009) \\
& Farrapeira et al. (2010) \\
Canaries & Moro et al. (2003) \\
England & Arenas et al. (2006) \\
Europe & Gollasch et al. (2002) \\
Hellenic sea & Pancucci-Papadopoulou et al. (2005) \\
India & Anil et al. (2002) \\
Madeira & Wirtz et al. (2006) \\
Mediterranean Sea & Zenetos et al. (2005) \\
New Zealand & Cranfield et al. (1998) \\
South Africa & Robinson et al. (2005) \\
United States & Fuller (2009) \\
\hline
\end{tabular}

more complex systems such as estuaries, which are known to harbour a large number of barnacle species. In fact, the majority of species reported for the Azores are deep-water species (Southward 1998). Only nine shallow-water cirripedes occupy the intertidal, two of which are probably misclassified (Elminus cristallinus Gruvel, 1907 and Semibalanus balanoides (Linnaeus, 1767)). Of the remaining seven, four belong to the family Balanidae: Megabalanus azoricus (autochthonous), Balanus trigonus, A. amphitrite (now confirmed in the Azores) and A. eburneus (now confirmed in São Miguel Island). Except for M. azoricus, all these species are considered alien (Southward 1998). $P$. perforatus is a new record to add to the alien Balanidae established at the Azores. Although the species can occur sublittorally to $40 \mathrm{~m}$ depth and settle on floating objects, it was thought to be unable to cross sea barriers given its absence in both Madeira and the Azores Islands (Herbert et al. 2003). According to the same authors, successful larval development and settlement may depend on a degree of thermal stratification within the water column that is more likely to occur within sheltered bays than near rocky headlands. This may account for the species' occurrence on piers, built on sandy beaches within the relatively embayed coasts of the Ponta Delgada marina harbours. The presence of artificial substrates, including piers, and the increasing number of breakwaters, marinas and sea defences (the newly constructed marina) may have facilitated recent colonization along this coast.

Because of the fouling propensity of the reported species, given their natural distribution and locally limited establishment in the Azores, their introduction has surely been mediated by the increasing recreational boat traffic in the last years. They are well known for their invasive potential and thus need some preliminary effort in the management of their populations. Furthermore, given the importance of the marine recreational traffic in the Azores, there is an increased probability in the spread of non-native species, especially on a local scale (Bax et al. 2002).

Although local species number and thus probably competition for space are increasing, apparently no species has become outcompeted yet. The recorded alien species occur predominantly on man-made substrates and in heavily disturbed habitats, which are particularly susceptible to invasive species. Due to competition, some species, like A. amphitrite or P. perforatus, may be pressed to more unfavourable habitats such as harbours, where they are becoming abundant. Due to the young age of the Azorean islands, there has not been enough time for the evolution of endemic species. Moreover, species are still colonizing and spreading, filling unoccupied niches, a process fastened by man. As a result, more exotic species may take advantage of the favourable habitat characteristics and the recent climate change. 
Fig. 5 Percentage of exotic species among shallow-water Balanidae in several places of the world. Unframed values relate to large areas such as continents (Europe), countries (United States, South Africa, Australia, New Zealand, India) and the Mediterranean Sea. Dubious reports were not considered. Data were taken from the literature given in Table 2

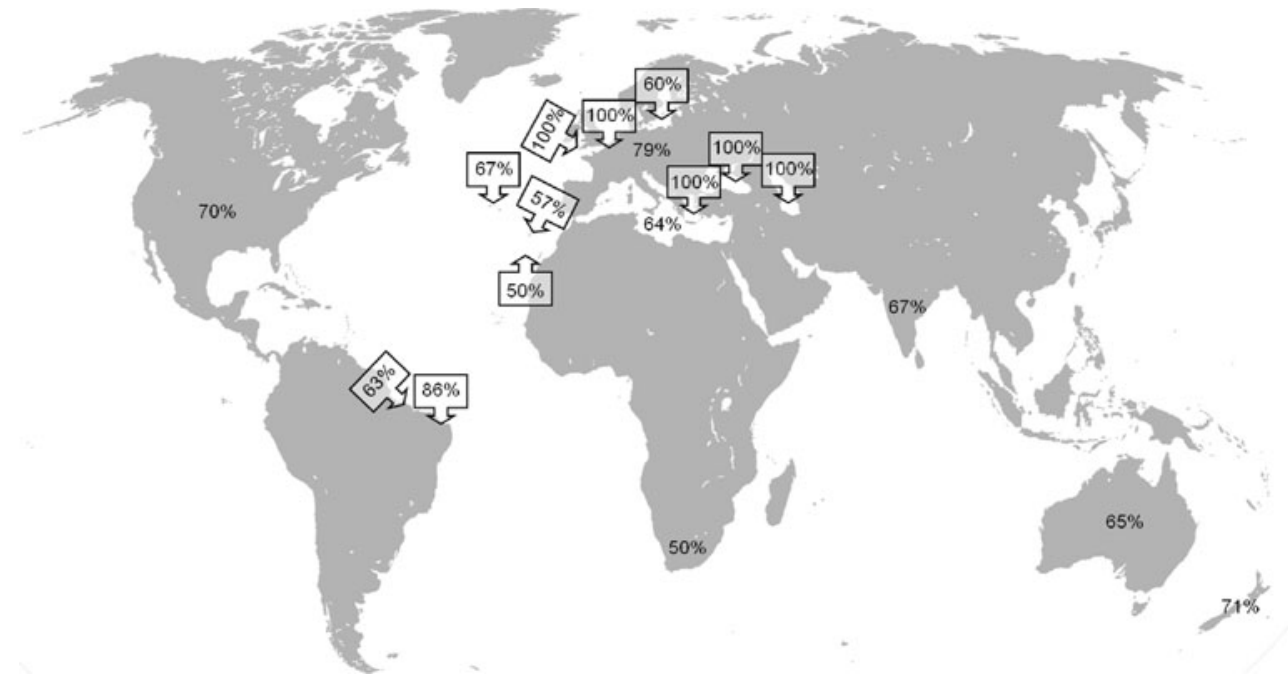

Future studies should address population dynamics of these alien barnacles, to understand their annual successions and impact on native species and address control and management protocols to allow a successful monitoring of these potentially invasive species.

Acknowledgments The authors would like to thank João Brum for help in the field procedures and Professor William Newman for the help in the species identification. Also, we would like to thank APSM (Administração dos Portos das Ilhas São Miguel e Santa Maria) and Port Authority of Ponta Delgada for logistical assistance and support. This study is part of the research project INSPECT (Introduced marine alien species in Portuguese estuaries and coastal areas: patterns of distribution and abundance, vectors and invading potential), funded by Fundação para a Ciência e a Tecnologia (PTDC/MAR/ 73579/2006) with a PhD support of Secretaria Regional da Ciência Tecnologia e Equipamentos (scholarship M3.1.2/F/019/2007).

\section{References}

Anil AC, Venkat K, Sawant SS, DileepKumar M, Dhargalkar VK, Ramaiah N, Harkantra SN, Ansari ZA (2002) Marine bioinvasion: concern for ecology and shipping. Curr Sci India 83:214-218

Apte S, Holland BS, Godwin LS, Gardner JPA (2000) Jumping ship: a stepping stone event mediating transfer of a non-indigenous species via a potentially unsuitable environment. Biol Invasions 2:75-79

Arenas F, Bishop JDD, Carlton JT, Dyrynda PJ, Farnham WF, Gonzalez DJ, Jacobs MW, Lambert C, Lambert G, Nielsen SE, Pederson JA, Porter JS, Ward S, Wood CA (2006) Alien species and other notable records from a rapid assessment survey of marinas on the south coast of England. J Mar Biol Assoc UK 86:1329-1337

Arnsberg AL (2001) The barnacles: Cirripedia. In: Shanks AL (ed) An identification guide to the larval marine invertebrates of the Pacific Northwest. Oregon State University Press, Corvallis, pp 156-175

Bassindale R (1964) British barnacles with keys and notes for the identification of the species. Synopes of the British fauna no. 14 . Linnean Society of London, London

Bax N, Hayes K, Marshall A, Parry D, Thresher R (2002) Man-made marinas as sheltered islands for alien marine organisms: establishment and eradication of an alien invasive marine species. In: Veitch CR, Clout MN (eds) Turning the tide: the eradication of invasive species. Occasional Paper of the IUCN species survival commission no. 27, pp 27-39

Bax N, Williamson A, Aguero M, Gonzalez E, Geeves W (2003) Marine invasive alien species: a threat to global biodiversity. Mar Policy 27:313-323

Bishop MWH (1950) Distribution of Amphibalanus amphitrite Darwin var. denticulata (Broch). Nature 165:409

Bishop MWH (1951) Distribution of barnacles by ships. Nature 167:531

Buizer DAG (1978) First autochthonous records of Amphibalanus perforatus Bruguière (Cirripedia, Balanomorpha) and Conchoderma auritum (L.) (Cirripedia, Lepadomorpha) in the coastal waters of the Netherlands. Zool Bijdr 23:34-37

Buizer DAG (1980) Amphibalanus tintinnabulum (Linnaeus 1758) autochthonous in the Netherlands, with notes on size and growth rate of other operculate barnacles (Cirripedia, Balanomorpha). Bull Zool Mus Univ Amsterdam 7:149-154

Cardigos F, Tempera F, Ávila S, Gonçalves J, Colaço A, Santos RS (2006) Nonindigenous marine species of the Azores. Helgol Mar Res 60:160-169

Carlton JT (1985) Transoceanic and interoceanic dispersal of coastal marine organisms: the biology of ballast water. Oceanogr Mar Biol Ann Rev 23:313-371

Carlton JT, Geller JB (1993) Ecological roulette: biological invasions and the global transport of nonindigenous marine organisms. Science 261:78-82

Carlton JT, Newman W, Pitombo FB (2011) Barnacle invasions: introduced, cryptogenic, and expanding range of Cirripedia North and South America. In: Galil BS, Clark PF, Carlton JT (eds) In the wrong place-alien marine crustaceans: distribution, biology and impacts. Springer, London, pp 159-213

Chakrabarti SK (1991) Wave forces on offshore structures, handbook of coastal and ocean engineering. Vol. 2, Offshore structures, marine foundations, sediment processes, and modelling. Gulf Publishing Company, Houston

Costlow JD Jr, Bookhout CG (1957) Larval development of Amphibalanus eburneus in the laboratory. Biol Bull 112:313-324

Costlow JD Jr, Bookhout CG (1958) Larval development of Amphibalanus amphitrite var. denticulata Broch reared in the laboratory. Biol Bull 114:284-295

Cranfield HJ, Gordon DP, Willan RC, Marshall BA, Battershill CN, Francis MP, Nelson WA, Glasby CJ, Read GB (1998) Adventive marine species in New Zealand. NIWA Tech Rep 34:48 
Crisp DJ (1976) Settlement responses in marine organisms. In: Newell RC (ed) Adaptations to environment. Butterworths, London, pp 83-124

Depledge MH, Weeks JM, Martins AF, Cunha RC, Costa A (1992) The Azores: exploitation and pollution of the coastal ecosystem. Mar Pollut Bull 24:433-435

Dionísio M, Costa A, Rodrigues, A (2011) Re-examination of Megabalanus azoricus (Cirripedia, Balanomorpha): a natural and edible resource to preserve. Mar Biodivers Rec (in press) (MBDR-03-11-OA-0031)

Farrapeira CMR (2008) Cirripedia Balanomorpha del estuario del Río Paripe (Isla de Itamaracá, Pernambuco, Brasil). Biota Neotrop $8: 31-39$

Farrapeira CMR (2009) Barnacles (Crustacea: Cirripedia) of the estuarine and marine areas of the Port of Recife (PernambucoBrazil): a monitoring study for bioinvasion. Cah Biol Mar 50:119-129

Farrapeira CMR, Ferreira GFA, Tenorio DO (2010) Intra-regional transportation of a tugboat fouling community between the ports of Recife and Natal, northeast Brazil. Braz J Oceanogr 58:1-14

Foster BA (1987) Barnacle ecology and adaptation. In: Southward AJ (ed) Crustacean issues V. barnacle biology. Balkema, Rotterdam, pp 113-133

Foster BA, Willan RC (1979) Foreign barnacles transported to New Zealand on an oil platform. NZ J Mar Freshw Res 13:143-149

Fuller P (2009) NAS - Nonindigenous aquatic species on the web. http:// nas.er.usgs.gov/queries/SpeciesList.aspx?Group=Crustaceans. Accessed 25 October 2010

Godwin LS (2003) Hull fouling of maritime vessels as a pathway for marine species invasions to the Hawaiian Islands. Biofouling 19(suppl):123-131

Gollasch S, MacDonald E, Belson S, Botnen H, Christensen JT, Hamer JP, Houvenaghel G, Jelmert A, Lucas IAN, Masson D, McCollin T, Olenin S, Persson A, Wallentinus I, Wetsteyn LPMJ, Wittling T (2002) Life in ballast tanks. In: Leppäkoski E, Gollasch $\mathrm{S}$, Olenin $\mathrm{S}$ (eds) Invasive aquatic species of Europe: distribution, impacts and management. Kluwer, Dordrecht, pp 217-231

Gould WJ (1985) Physical oceanography of the Azores front. Progr Oceanogr 14:167-190

Gruvel A (1920) Cirrhipèdes provenant des campagnes scientifiques de S.A.S. 1 Prince de Monaco. Résultats des Campagnes Scientifiques accomplies sur son yacht par Albert Ier. Prince Souverain de Monaco 53:1-89 (pls1-7)

Harding JP (1962) Darwin's type specimens of varieties of Balanus amphitrite. Bull Br Mus Hist (Zool.) 9:271-296

Hayward PJ, Ryland JS (1999) Cheilostomatous Bryozoa: 2. Hippothooidea-Celleporoidea: notes for the identification of British species. Synopses of the British fauna (New Series), 2nd edn. Field Studies Council, Shrewsbury

Henry DP, McLaughlin PA (1975) The barnacles of the B. amphitrite complex (Cirripedia, Thoracica). Zool Verhandel 141:1-254

Herbert RJH, Hawkins SJ, Sheader M, Southward AJ (2003) Range extension and reproduction of the barnacle Balanus perforatus in the eastern English Channel. J Mar Biol Assoc UK 83:73-82

Houghton DR (1978) Marine fouling and offshore structures. Ocean Manage 4:347-352

Jones DS (1992) A review of Australian fouling barnacles. Asian Mar Biol 9:89-100

Kaplan EH (1988) A field guide to southeastern and Caribbean seashores: Cape Hatteras to the Gulf coast, Florida, and the Caribbean. Houghton Mifflin Co, Boston

Kerckhof F, Cattrijsse A (2001) Exotic Cirripedia (Balanomorpha) from buoys off the Belgian coast. Mar Biodivers 31:245-254

Kerckhof F, Haelters J, Gollasch S (2007) Alien species in the marine and brackish ecosystem: the situation in Belgian waters. Aquat Invasions 2:243-257
Koukoura A, Matsa A (1998) The thoracican cirriped fauna of the Aegean Sea: new information, check list of the Mediterranean species, faunal comparisons. Senckenb Marit 28:133-142

Lavoie DM, Smith LD, Ruiz GM (1999) The potential for intracoastal transfer of nonindigenous species in the ballast water of ships. Estuar Coast Shelf Sci 48:551-654

Leppäkoski E, Gollasch S (2006) Risk assessment of Ballast water mediated species introductions-a Baltic sea approach. Report prepared for HELCOM, pp 111

Lipkin Y, Safriel U (1971) Intertidal zonation on rocky shores at Mikhmoret (Mediterranean, Israel). J Ecol 59:1-30

Matsui T, Shane G, Newman W (1964) On Amphibalanus eburneus Gould (Cirripedia, Thoracica) in Hawaii. Crustaceana 7:141-145

Moro MartínJL, Garrido MJ, Izquierdo I (2003) Lista de especies marinas de Canarias. Algas, hongos, plantas y animales. Consejería de Política Territorial y Medio Ambiente, Gobierno de Canarias

Morton B, Britton JC, Martins AMF (1998) Costal ecology of the Açores. Sociedade Afonso Chaves, Ponta Delgada

Newman WA, Ross A (1976) Revision of the balanomorph barnacles; including a catalogue of the species. San Diego Soc Nat Hist Mem 9:1-108

Newman WA, Zullo VA, Withers TH (1969) Cirripedia. In: Moore RC (ed) Treatise of invertebrate paleontology. Arthopoda 4, part R1. University of Kansas Press, Lawrence, pp 206-295

Palmer AR (1982) Predation and parallel evolution: recurrent parietal plate reduction in balanomorph barnacles. Paleobiology 8:31-44

Pancucci-Papadopoulou MA, Zenetos A, Corsini-Foka M, Politou CY (2005) Update of marine alien species in Hellenic waters. Mediterr Mar Sci 6:147-158

Panov V (2004) Internet-based information resources on aquatic alien species relevant to the Ponto-Caspian Region. In: Dumont $\mathrm{H}$, Shiganova TA, Niermann U (eds) Aquatic Invasions in the Black, Caspian, and Mediterranean Seas. Springer, New York, pp 257-269

Patel B, Crisp D (1960) The influence of temperature on the breeding and the moulting activities of some warm-water species of operculate barnacles. J Mar Biol Ass UK 39:667-680

Patil BT, Gajendragad MR, Ranganna G, Ramchandran T (1988) Effects of biofouling and corrosion on concrete structures. In: Thompson MF, Sarojini R, Nagabhushanam R (eds) Marine biodeterioration: advanced techniques applicable to the Indian Ocean. Balkema, Rotterdam, pp 715-724

Pelseneer P (1881a) Etudes sur la faune littorale de la Belgique (vers chétopodes et crustacés). Bull Inst R Sci Nat Belg 16:88-97

Pelseneer P (1881b) Etudes sur la faune littorale de la Belgique. Tuniciers, crustacés, vers, échinodermes et coelentérés recueillis en 1881 sur la côte belge. Bull Inst R Sci Nat Belg 16:152-156

Pitombo FB (2004) Phylogenetic analysis of the Balanidae (Cirripedia, Balanomorpha). Zool Scripta 33:261-276

Pollard RT, Pu S (1985) Structure and circulation of the upper Atlantic Ocean northeast of the Azores. Progr Oceanogr 14:443-462

Raymont JEG (1980) Plankton and productivity in the Oceans. Vol 1. Phytoplankton, 2nd edn. Pergamon Press, Oxford

Robinson TB, Griffiths CL, McQuaid CD, Rius M (2005) Marine alien species of South Africa—status and impacts. Afr J Mar Sci 27:297-306

Santos RS, Hawkins SJ, Monteiro LR, Alves M, Isidro EJ (1995) Marine research, resources and conservation in the Azores. Aquat Conserv 5:311-354

Shkedy Y, Fernandez D, Teague C, Vesecky J, Roughgarden J (1995) Detecting upwelling along the central coast of California during an El Niño year using HF-radar. Cont Shelf Res 15:803-814

Southward AJ (1962) The distribution of some plankton animals in the English Channel and approaches II: surveys with the Gulf III high-speed sampler, 1958-1960. J Mar Biol Ass UK 42:275-375 
Southward AJ (1975) On the evolutionary significance of the mode of feeding of Pogonophora. Z Zool Syst Evolforsch, Special Issue 13:77-85

Southward AJ (1998) New observations on barnacles (Crustacea:Cirripedia) of the Azores Region. Arquipel Life Mar Sci 16A:11-27

Southward AJ, Crisp DJ (1963) Catalogue of main marine fouling organisms (found on ships coming into European waters). Vol 1, Barnacles. Organization for Economic Cooperation and Development, Paris

Southward AJ, Burton RS, Coles SL, Dando PR, DeFelice RC, Hoover J, Parnell PE, Yamaguchi T, Newman WA (1998) Invasion of Hawaiian shores by an Atlantic barnacle. Mar Ecol Prog Ser 165:119-126

Streftaris N, Zenetos A, Papathanassiou E (2005) Globalisation in marine ecosystems: the story of non-indigenous marine species across European seas. Oceanogr Mar Biol Ann Rev 43:419-453

Stubbings HG (1967) The cirriped fauna of tropical west Africa. Bull Brit Mus Nat Hist Zool 15:229-319

Utinomi H (1960) On the world-wide dispersal of a Hawaiian barnacle, Amphibalanus amphitrite hawaiiensis Broch. Pac Sci $14: 43-50$

Van Syoc R (2009) Cirripedia. In: Wehrtmann IS, Cortes J (eds) Marine biodiversity of costa rica, Central America. Springer, New York, pp 283-290
Voss GL (1980) Seashore life of Florida and the Caribbean. Dover Publications, Mineola

Wirtz P, Araújo R, Southward AJ (2006) Cirripedia of Madeira. Helgol Mar Res 60:207-212

Wolfram J, Theophanatos A (1985) The effects of marine fouling on the fluid loading of cylinders: some experimental results. Offshore technology conference, 6-9 May, Houston, Texas

Wu R, Levings C, Randall D (1977) Differences in energy partitioning between crowded and uncrowded individual barnacles. Can J Zool 55:643-647

Young PS (1998) Cirripedia (Crustacea) from the "Campagne BiAzores" in the Azores region, including a generic revision of Verrucidae. Zoosystema 20:31-92

Zardus JD, Hadfield MG (2005) Multiple origins and incursions of the Atlantic barnacle Chthamalus proteus in the Pacific. Mol Ecol 14:3719-3733

Zenetos A, Çinar ME, Pancucci-Papadopoulou MA, Harmelin JG, Furnari G, Andaloro F, Bellou N, Streftaris N, Zibrowius H (2005) Annotated list of marine alien species in the Mediterranean with records of the worst invasive species. Mediterr Mar Sci 6:63-118

Zullo VA (1992) Amphibalanus trigonus Darwin (Cirripedia, Balaninae) in the Atlantic basin: an introduced species? Bull Mar Sci 50:66-74 